José Florencio F. Lapeña, Jr., M.A., M.D.

Department of Otorhinolaryngology

College of Medicine, University of the Philippines Manila

Department of Otorhinolaryngology

Head and Neck Surgery

East Avenue Medical Center, Diliman, Quezon City
Correspondence: Prof. Dr. José Florencio F. Lapeña, Jr.

Department of Otorhinolaryngology

Ward 10, Philippine General Hospital

University of the Philippines Manila

Taft Ave., Ermita, Manila 1000

Philippines

Phone (632) 5264360

Telefax (632) 5244455

Email lapenajf@upm.edu.ph

Reprints will not be available from the author.

The author declared that this represents original material that is not being considered for publication or has not been published or accepted for publication elsewhere, in full or in part, in print or electronic media; that the manuscript has been read and approved by the author, that the requirements for authorship have been met by the author, and that the author believes that the manuscript represents honest work.

Disclosures: The author has no relevant financial or other (including personal) relationships, intellectual passion, political or religious beliefs, and institutional affiliations that might lead to a conflict of interest.

\section{Rizal, Renaissance and Reform: Reflections on Ophthalmology and Otorhinolaryngology in the Philippine General Hospital}

The nineteenth of June 2011 marks a century and fifty years since the birth of JoséProtasio Rizal in 1861. ${ }^{1}$ The ninth of November 2011 also marks the Golden Jubilee of the foundation of the Departments of Ophthalmology and Otorhinolaryngology of the Philippine General Hospital (PGH) in 1961, dividing the original Department of Eye, Ear, Nose and Throat that was established a century ago in May 1911. The national hero of the Philippines and Pride of the Malay Race ${ }^{2}$ is immortalized in countless ways, reflecting his multiple accomplishments that mark a true renaissance individual. The two departments of the national University of the Philippines (UP) have likewise made their mark in pace with the many achievements of their alumni. Rizal was a polyglot and polymath poet, painter, sculptor, sportsman, scientist and patriot, whose writings led to his execution and sparked the Philippine Revolution of 1898. ${ }^{1,3} \mathrm{He}$ was also a physician and an ophthalmologist who insightfully dissected the ills of his patients and society. What have the departments and their hospital contributed to health and to humankind?

If precedence were the measure of significance, the pioneering "firsts" would have to include the first laryngo-fissure operation by founding department head Dr. Reinhard Rembe in 1913, the first intracapsular cataract lens extraction in the country using a suction erisophake after the technique of Barraquer by the next chair (and nephew of the national hero) Dr. Aristeo Rizal Ubaldo in 1920, the first laryngectomy by Drs. Ubaldo and founding president of the Philippine Academy of Ophthalmology Antonio S. Fernando in 1923 and the first labyrinthectomy by Drs. Ubaldo and Vicencio C. Alcantara in 1927.5 There was a time when the chairs and senior consultants of most departments of otorhinolaryngology head and neck surgery in the Philippines were alumni of the UP-PGH, as was the leadership of the Philippine Society of Otolaryngology and Bronchoesophagology (later Philippine Society of Otolaryngology Head and Neck Surgery) which separated from the Philippine Ophthalmological and Otolaryngological Society (subsequently Philippine Academy of Ophthalmology and Otolaryngology) in 1956. But those are bygone days, and the folly of resting on one's laurels becomes all too apparent, as these are quickly eclipsed by the capabilities of newer, better-equipped health care facilities that are manned by experts trained in their respective institutions. Thus the race to super-specialize and sub-specialize, perhaps to regain lost ground and primacy at the expense of tertiary general health care has become the battle cry for some, led by the present administration of the PGH. 
And yet, the majority of Filipinos still do not have access to primary health care. ${ }^{6}$ They who do not even have the services of a basic physician much less can avail of special care of their sight, hearing and balance, smell and taste, breathing, swallowing or speaking, nor of the face with which they face the world. Witness the number of adults with unrepaired cleft lips and untreated head and neck tumors roaming the streets of the city.

The UP College of Medicine (UPCM) founded in 1905 aims "towards leadership and excellence in community-oriented medical education, research and service directed particularly to the underserved." As the teaching hospital of the UPCM, with whom it shares such academic and clinical departments as Ophthalmology and Otorhinolaryngology, the hundred-year-old Philippine General Hospital and its leadership cannot and must not turn a blind eye or deaf ear to the underserved it is mandated to serve. Its true strength lies in relevance, which is quickly lost if it succumbs to the delusionary glitter of super-specialization beyond the reach of most people. Of what benefit is it to be the "first", if it does not redound to the good of the "many?"

Of Rizal, it has been said"to his patients he gave sight; and to his country he gave vision." ${ }^{17}$ As the Departments of Ophthalmology and Otorhinolaryngology pursue the arts and sciences of vision, hearing and balance, olfaction and gustation, respiration and deglutition, phonation and facial expression, may they sharpen the sensitivity of health providers in PGH and other loco-regional general hospitals to the real issues of health and humankind in the developing world and embolden us to overcome the apathy to "hear no evil, see no evil, speak no evil."

\footnotetext{
REFERENCES

1. Craig A. Lineage, life and labors of José Rizal: Philippine patriot. In: The Project Gutenberg EBook of Lineage, Life and Labors of Jose Rizal: Philippine Patriot, A Study of the Growth of Free Ideas in the Trans-Pacific American Territory by Austin Craig Manila: Philippine Education Publishing Co., 1913. [Online EBook \# 6867 Cited November 23, 2010.] Available from: http:// www.gutenberg.org/ebooks/6867.

2. Palma R. The Pride of the Malay Race: A biography of José Rizal. New York: Prentice-Hall, 1949.

3. Laubach FC. Rizal: man and martyr. Manila: Community Publishers, 1936. [copyright 1909 by Frank C. Laubach, Online Version] Available at: http://joserizal.info/Biography/man_and_ martyr/portal.htm Accessed November 26, 2010.

4. Lapeña JF. José Protacio Rizal (1861-1896): physician and Philippine national hero. Singapore Med J. 2011 June; 52(6): (Forthcoming).

5. Jamir JC, Lapeña JF. Annual report of the department of otorhinolaryngology 1998. History excerpted in: Arcellana-Nuqui EY, Danguilan JL, Agbayani BF, Alfonso OM, Balgos AA, Caballes $A B$, et al., (editors). Siyento: the UP College of Medicine centennial commemorative book. Manila: UPCM Centennial Executive Committee, 2005.

6. Blueprint for universal health care 2010-2015 and beyond. The UP Forum 2009 Nov-Dec 10(6) [cited 2011 May 20] Available from: http://akane.upd.edu.ph/upforum.php?issue=34\&i=289

7. Ravin TB. José Rizal: Philippine national hero and ophthalmologist. Arch Ophthalmol 2011 Feb; 119(2):280-84. Available at: http://archopht.ama-assn.org/cgi/content/full/119/2/280 Accessed November 26, 2010.0
} 